\title{
Influence of the Assembly Method of Sleeve Joints on Their Strength
}

\author{
Anna Rudawska ${ }^{1}$, Izabela Miturska ${ }^{1}$, Magd Abdel Wahab ${ }^{2}$, Dana Stančekováa ${ }^{3}$, Miroslava Ťavodová ${ }^{4}$ \\ ${ }^{1}$ Lublin University of Technology, Faculty of Mechanical Engineering, Nadbystrzycka 36, 20-618 Lublin, PL. \\ E-mail: i.miturska@pollub.pl, a.rudawska@pollub.pl \\ ${ }^{2}$ Ghent University, Faculty of Engineering and Architecture, Zwijnaarde, Sint-Pietersnieuwstraat 41, 9000 Ghent, \\ Belgium. E-mail: Magd.AbdelWahab@UGent.be \\ ${ }^{3}$ University of Zilina, Faculty of Mechanical Engineering, Department of Machining and Manufacturing Technol- \\ ogies, Univerzitna 8215/1, 01026 Žilina, Slovakia. E-mail: dana.stancekova@ fstroj.uniza.sk \\ ${ }^{4}$ Technical University in Zvole, Faculty of Environmental and Manufacturing Technology, Študentská 26, 96001 \\ Zvolen, Slovakia. E-mail: tavodova@tuzvo.sk
}

The aim of the study was to compare the strength of assembly joints of sleeve elements made of different structural, polymeric materials. Experimental tests were carried out to determine the mechanical properties of adhesive and welded joints. Adhesive joints were made of polyvinyl chloride pipes with the use of three types of adhesives: Epidian 53/PAC/100:80, Epidian 53/TFF/100:22, Vodaro 15010-VO. The welded joints were made of polypropylene pipes. All of the joints have been made with the use of a pipe fitting allowing for correct joints. Then the completed joints were subjected to destructive strength tests. The obtained results made it possible to carry out statistical analysis, which aimed at determining significant differences between the various methods of assembly. The tests carried out proved that the adhesive joints made with the Vodaro 15010-VO one-component adhesive were characterized by the highest strength - 2.30 MPa. The lowest strength was obtained in the case of adhesive joints made with Epidian 53/TFF/100:22 - 0.45 MPa epoxy ad-hesive composition. Statistical analysis showed that the strength obtained in case of adhesive joints made with epoxy compositions differs significantly from the strength of adhesive joints made with Vodaro adhe-sive. No significant differences at the assumed level of significance $\alpha=0.05$ were also observed in the case of the strength of PP-R adhesive joints made with Vodaro adhesive and the strength of PVC-U welded joints.

Keywords: Adhesive joints, Welded joints, Sleeve joints

\section{Introduction}

Bonding is the durable joining of individual cells into a single unit. During the bonding process, atomic and molecular bonds are formed between the jointed elements, which means a permanent joint. Disconnection of this type of joint is not possible without its destruction. Joints created as a result of the bonding process are called cohesion or inseparable joints [4, 28].

Nowadays, cohesion joints are widely used in practically every area of life, and above all in various areas of technology. Bonding allows different types of materials to be jointed together, which enables the creation of different structures, both for supporting structures, light or heavy loads, but also for making joints working in different conditions $[1,8,18,19]]$. In order to select a suitable joint method for the load condition considered by the structural engineer, a strength analysis of the statically loaded joint must be carried out. The strength analysis in the form of analytical calculations allows to choose the optimal method of joint from many existing methods: welding, soldering or adhesive bonding. The subject of the article were assembly sleeve joints made by such methods as: adhesive bonding and welding. Adherends were made of two types of materials - polyvinyl chloride PVC-U and polypropylene PP-R. Taking into account the properties of the materials used, the appropriate bonding method was selected.

Adhesive is a very popular method of joining elements, among others: in the construction of technological pipelines made of plastic [16]. Ścieszka S.F., Żołnierz M. and Sionkowska A. [12,22] presented that for adhesive joints, fittings and pipes made of plastics such as unplasticized polyvinyl chloride (PVC-U), chlorinated polyvinyl chloride (PVC-C) and acrylonitrile-butadiene-styrene copolymer (ABS) are suitable . Rudawska A., Dolez P., Arnott D. and other [3, 7, 21] consider that adhesives are also more and more often used to various kinds of repair and maintenance works, especially in field conditions, as an immediate measure aimed at temporary repair of a given element.

Many authors presented that, compared to other methods [25, 26], the ahesive bonding is relatively easy to use and, in many cases, does not require specialist 
tools, which leads to a significant reduction of production costs. Moreover the process of adhesive bonding is not complicated and does not require additional equipment such as welded or soldered joints. However, special attention should be paid to a few important details, which may decide about the quality and durability of the joint, and thus the reliability and safety of the entire installation and construction [16].

Welding is a permanent combination of two or more elements of the same chemical composition, which is obtained at elevated temperatures and pressures [4]. In the process of welding polymer parts, they are joined by plasticizing the contact surface, then a high clamping force is exerted, which causes the polymer to flow and deform at the point of welding [2]. During the realization of the study, welding with the use of fittings, also known as socket welding, was applied $[5,8,11]$. Socket welding is a very popular method of joining polymer pipes. This method of assembly is not complicated and is a fast method of permanent joints of sleeve elements. Sleeve welding is very similar to butt welding, but the difference is in the way the heat is supplied to the area to be joined. The diagram of the welding process is shown in Fig. 1.

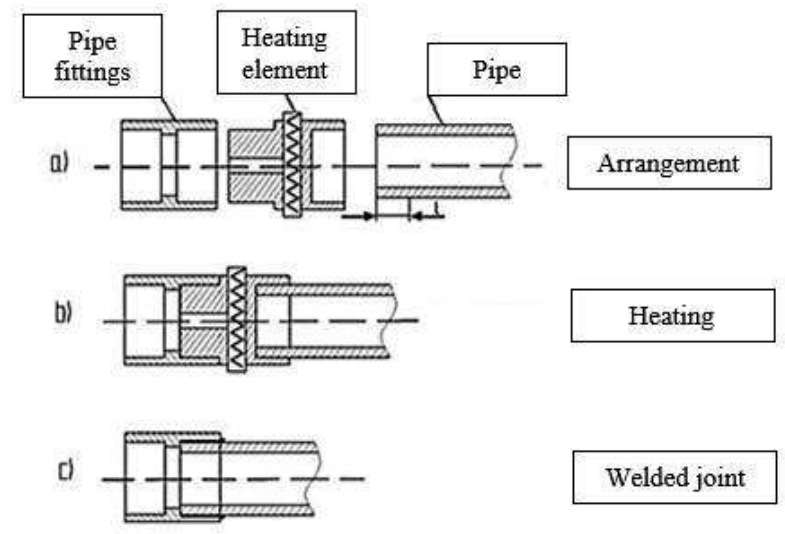

Fig. 1 Schematic diagram of the socket welding process [own work based on 6$]$

In socket welding, fittings ( pipe fittings, elbows, sockets, tees, etc.) are used, which, just like pipes, slide onto the heated heating pad located on the heating cooktop. The heating pad consists of a heating sleeve and a heating bolt. A separate set of covers is used for each pipe diameter. Joint welding, also known as polyfusion welding, is used exclusively for joining pipes. Grewell et al. [9] presented that, this method is mainly used for water systems made of polypropylene and polyethylene pipes. Appropriate selection of welding parameters allows to obtain a durable joint in a short time. These parameters include: welding temperature, clamping length, compensation allowance, welding time, break time (i.e. time between the end of the welding process and the application of pressure force), pressure force of the welded elements to the hot plate and welding time. Selection of these factors depends on the type of welded material, dimension of welded elements and the purpose of the joints.

The aim of the study was to compare the strength of the joints in order to check the effectiveness of universal adhesives, which can include epoxy adhesive compositions and an adhesive dedicated to specific purposes and specific materials. Taking into account the wide range of applications of joints of such type as presented in the paper, it seems to be reasonable strength analysis of such joints. In addition, a comparison of the strength of adhesive and welded joints may be useful for people who do not have the appropriate equipment and facilities to perform welded joints. It may turn out that bonding is a suitable alternative to welding of elements made of polymers.

\section{Studies methods}

\subsection{Characteristics of adherends}

Three types of pipes were used in the experimental studies: polyvinyl chloride (PVC-U) and polypropylene (PP-R) pipes.

Polyvinyl chloride (PVC-U) pipes are characterized by high corrosion resistance. They do not react with water and its compounds and are resistant to many acids and alkalis. Pipes made of this material are used in various types of sewerage and drainage systems and as shielding pipes for cables, as well as in cold water systems $[17,20]$.

Polypropylene pipes (PP-R) are very popular and easily accessible. They are characterized by corrosion resistance, low thermal conductivity, do not react with water and its compounds. PP-R pipes are used for hot and cold water, central heating, sewage, drainage and protective installations. The table below lists the recommended operating parameters for each material.

Tab. 1 Recommended operating parameters of materials used in research

\begin{tabular}{|c|c|c|}
\hline Material & PVC-U & PP-R \\
\hline $\begin{array}{c}\text { Working temperature } \\
{\left[{ }^{\circ} \mathbf{C}\right]}\end{array}$ & $0-60$ & $0-90$ \\
\hline $\begin{array}{c}\text { Maximum working } \\
\text { pressure [MPa] }\end{array}$ & 1.6 & 0.6 \\
\hline
\end{tabular}

Samples of $50 \mathrm{~mm}$ length cut from pipes with a diameter of $ø 25 \mathrm{~mm}$ were used in the tests.

\subsection{Assembly methods}

Two methods of tube-assembly were used in the course of the research: adhesive bonding and welding. Individual methods of bonding were selected taking into account the properties of the used materials. In the research, butt joints with the use of the following pipe fittings were used. 


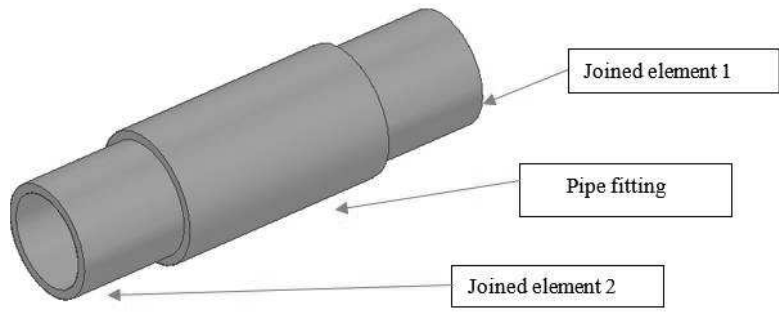

Fig. 2Shape of the butt joint with the use of the pipe fitting

Two universal epoxy adhesive compositions were used in the process of adhesive bonding: Epidian 53/PAC/100:80, Epidian 53/TFF/100:22, and Vodaro 15010-VO/100 one-component adhesive. Epoxy adhesive compositions are adhesives based on epoxy resin and curing agent added in the appropriate proportion, recommended by the producer. Epidian 53 is a pre-modified, water-insoluble epoxy resin in the form of a light yellow, viscous liquid with a smell characteristic of styrene. The density of this resin is $1.11-1.15 \mathrm{~g} / \mathrm{cm} 3$ at $20^{\circ} \mathrm{C}$ and the viscosity at $25^{\circ} \mathrm{C}$ is 900-1500 $\mathrm{mPa} \cdot \mathrm{s}$. It can be used in cold bonding of glass metals, ceramics and many rigid structures, because the joint is not very resistant to deformation.
PAC curing agent is a polyamide current agent. Compositions of epoxy resins with PAC curig agent are used as modified popular adhesives for everyday household applications and for joining elements exposed to deformation, e.g. for bonding thin metal sheets or joining rubber with metal. TFF curing agent is a curing agent for liquid epoxy resins and compositions based on them used in construction, where work is carried out in low temperature conditions, often at high humidity. The good chemical resistance of such compositions in many aggressive environments qualifies TFF curing agent for cured of anti-corrosion linings in industry. A positive hygienic rating allows it to be used for various types of epoxy coatings in public utility rooms and the food industry. The one-component adhesive Vodaro 150010-VO belongs to the group of aggressive adhesives. It is designed for bonding hot and cold water systems. It allows for permanent joint of pipes and fittings. It is characterized by exceptional efficiency, durability and resistance to corrosive factors [9].

The properties of the adhesives used in the tests are shown in the Tab. 2.

Tab. 2 Properties of the adhesives used in the tests $[11,17,20]$

\begin{tabular}{|c|c|c|c|}
\hline \multirow{2}{*}{ Density } & $\begin{array}{c}\text { Type of adhesive } \\
\text { Epoxy adhesive compositi- } \\
\text { ons }\end{array}$ & $\begin{array}{c}\text { Epidian 53/TFF/100:22 } \\
\text { epoxy adhesive compositi- } \\
\text { ons }\end{array}$ & $\begin{array}{c}\text { Vodaro 15010- } \\
\text { vo/100 one-compo- } \\
\text { nent adhesive }\end{array}$ \\
\hline Viscosity & $\begin{array}{c}\text { density of curent agent } \\
1.10-1.20 \mathrm{~g} / \mathrm{cm}^{3}\left(\text { at } 20^{\circ} \mathrm{C}\right)\end{array}$ & $\begin{array}{c}\text { density of curent agent } \\
1.15-1.20 \mathrm{~g} / \mathrm{cm}^{3}\left(\text { at } 20^{\circ} \mathrm{C}\right)\end{array}$ & $0.96 \mathrm{~g} / \mathrm{cm}^{3}\left(\right.$ at $\left.20^{\circ} \mathrm{C}\right)$ \\
\hline $\begin{array}{c}\text { viscosity of curent agent } \\
\text { Tabular ten- } \\
\text { sile strength } \\
{[\mathrm{MPa}]}\end{array}$ & $\begin{array}{c}\text { viscosity of curent agent } \\
\max .10000 \mathrm{mPa} \cdot \mathrm{s}\left(\mathrm{at} 25^{\circ} \mathrm{C}\right)\end{array}$ & $\begin{array}{c}400-800 \mathrm{mPa} \cdot \mathrm{s}(\mathrm{at} \\
\left.25^{\circ} \mathrm{C}\right)\end{array}$ \\
\hline
\end{tabular}

The process of adhesive bonding was carried out in the following steps:

- Preparation of surfaces of joined elements. At first, the edges of the pipes were bevelled and cleaned. A correctly bevelled and rounded pipe end ensures that the adhesive layer is not scraped off when the pipe is inserted into the pipe fitting. The bonded surfaces, i.e. the external part of the pipe and the internal part of the pipe fitting, were thoroughly cleaned of any dirt. The cleaned surfaces were left to dry before direct application of adhesive.

- Apply the adhesive onto the component to be bonded. For this purpose, a brush of suitable diameter is used to apply an even layer of adhesive on the surfaces to be bonded.
- Joint of bonded elements. Immediately after application of the adhesive, the two parts were joined by inserting and turning, which ensures even distribution of the adhesive.

- Removal of the flash. Correctly made joints is characterized by the appearance of a thin layer of adhesive around the pipe at the base of the pipe fitting [21]. It was removed directly after the stage of joining the jointed elements with the use of soft paper, thanks to which the joint was characterized by greater aesthetics.

Joints were made in laboratory conditions at $23 \pm 2{ }^{\circ} \mathrm{C}$ and $24 \pm 3 \%$ humidity. For each adhesive type, 10 joints were made using PVC-U pipes and pipe fittings.

The welding process began with the preparation of 
the surface of pipes and pipe fittings intended for the joining process. For this purpose, dust-free paper was used. Heating pads were also cleaned, because it is very important that they are free of impurities before the assembly process. In the next stage, the internal part of the fitting and the external part of the pipes were heated until a visible flow was created. Then the pipe was pressed into the fitting, while maintaining the alignment of the joint. The cooktop of the welding machine was heated to a temperature of $262^{\circ} \mathrm{C}$. A welding machine for Dedra $800 \mathrm{~W} / 1500 \mathrm{~W}$ polymer pipes was used for welding. The welding process was carried out in workshop conditions, in a draught-free room at $23^{\circ} \mathrm{C}$ at $24 \%$ air humidity. 10 joints were made with the use of PP-R pipes and pipe fittings

\subsection{Joints geometry}

During the realization of the study, in the case of all materials, the butt joints were made with the use of pipe fittings. The dimensions of these joints and their actual appearance are shown in the figures below (Fig.3 - Fig.6).

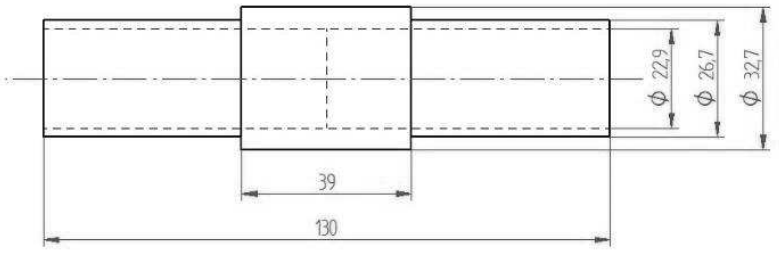

Fig. 3 Dimensions of PVC-U pipes and pipe fittings used for adhesive joints

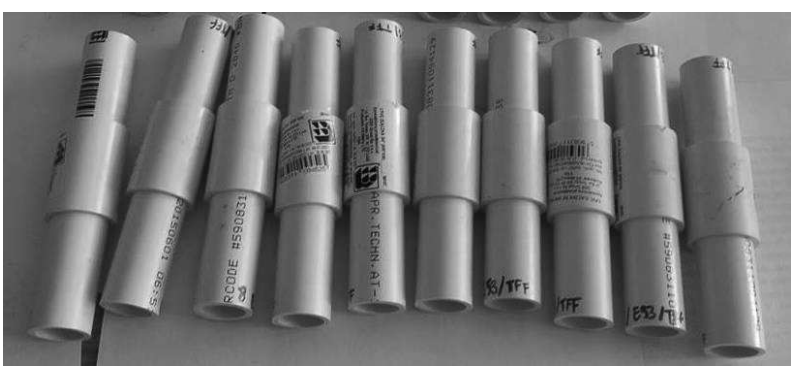

Fig. 4 Adhesive butt joints with pipe fittings made of PVC$U$ materials

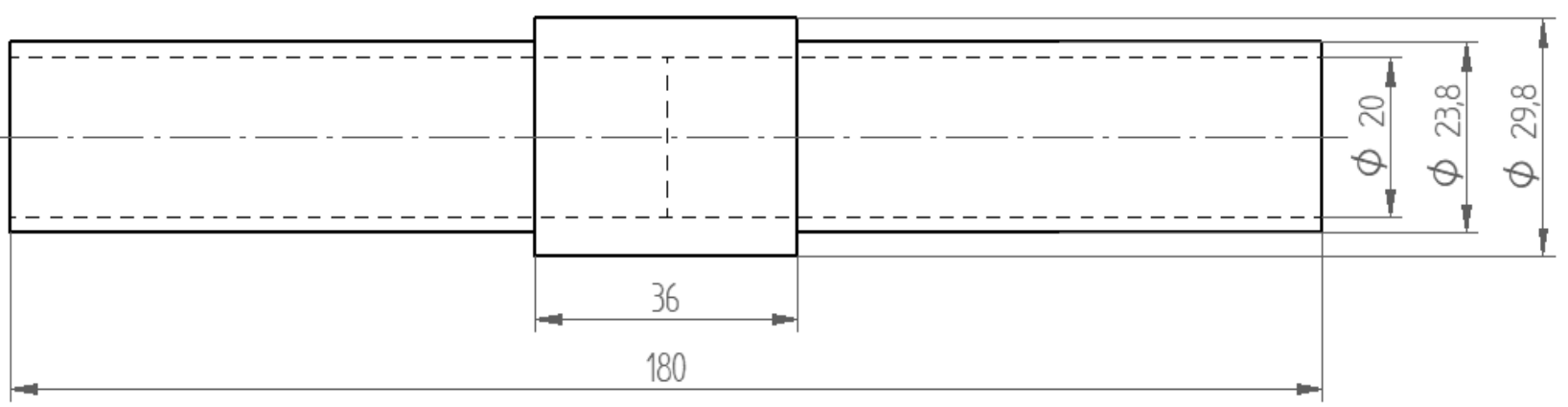

Fig. 5 Dimensions of pipes and pipe fittings PP-R used for welded joints

Tab. 3 Properties of the adhesives used in the tests

\begin{tabular}{|c|c|c|c|c|c|}
\hline \multirow{2}{*}{\multicolumn{2}{|c|}{$\begin{array}{l}\text { Sample num- } \\
\text { ber }\end{array}$}} & \multirow{3}{*}{$\begin{array}{c}\text { Epidian 53/PAC/100:80 } \\
\text { epoxy adhesive compo- } \\
\text { sitions } \\
132.20\end{array}$} & \multicolumn{3}{|c|}{ Dimensions of samples } \\
\hline & & & $\begin{array}{c}\text { Epidian 53/TFF/100:22 } \\
\text { epoxy adhesive compo- } \\
\text { sitions }\end{array}$ & $\begin{array}{l}\text { Vodaro } 15010- \\
\text { VO/100 one- } \\
\text { component ad- } \\
\text { hesive }\end{array}$ & $\begin{array}{c}\text { Socket } \\
\text { welded } \\
\text { joints }\end{array}$ \\
\hline 1 & \multirow{10}{*}{$\begin{array}{c}\text { Length of } \\
\text { sample } \\
\text { [mm] }\end{array}$} & & 133.10 & 131.10 & 181.00 \\
\hline 2 & & 135.00 & 131.90 & 131.80 & 182.00 \\
\hline 3 & & 133.50 & 130.50 & 132.10 & 191.00 \\
\hline 4 & & 132.10 & 132.00 & 131.40 & 181.10 \\
\hline 5 & & 134.90 & 131.10 & 130.10 & 181.00 \\
\hline 6 & & 134.10 & 133.80 & 131.20 & 182.10 \\
\hline 7 & & 134.10 & 131.00 & 130.10 & 182.50 \\
\hline 8 & & 133.10 & 133.50 & 132.00 & 183.00 \\
\hline 9 & & 134.00 & 133.50 & 131.00 & 182.80 \\
\hline 10 & & 133.40 & 132.00 & 130.20 & 183.10 \\
\hline \multicolumn{2}{|r|}{ Average } & 133.64 & 132.24 & 131.10 & 182.96 \\
\hline \multicolumn{2}{|c|}{$\begin{array}{c}\text { Standard devi- } \\
\text { ation }\end{array}$} & 0.93 & 1.15 & 0.72 & 2.78 \\
\hline
\end{tabular}




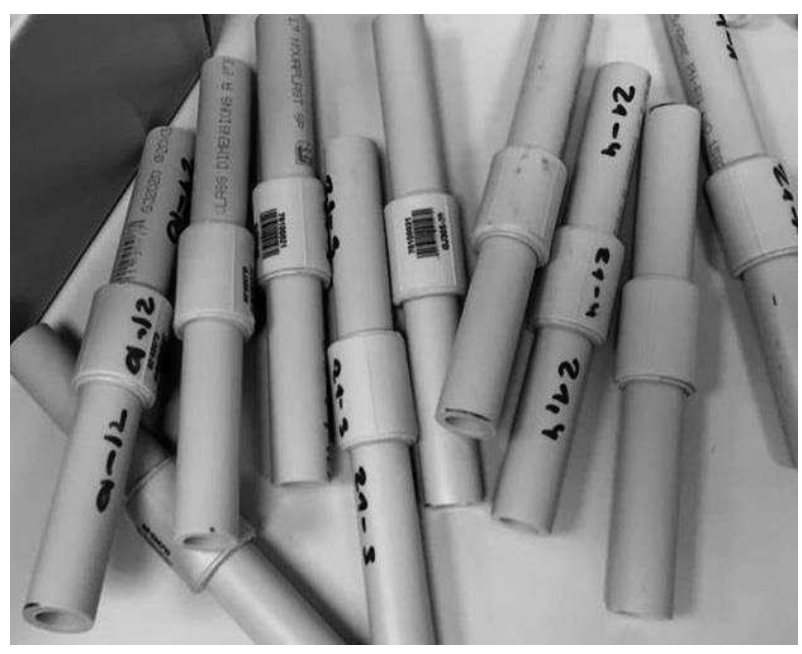

Fig. 6 Socket welded joints made of PP-R materials

Variable type of joints prepared in this way were left for 5 days. For adhesive bonds, this time is necessary because for the adhesive to achieve its properties, it is necessary to leave it to cure [10]. Before the destructive tests were carried out, the joints obtained were measured. The real dimensions of the adhesive joints are summarized in Tab. 3 .

The length of the pipe fittings was fixed - $39 \mathrm{~mm}$ for adhesive joints and $36 \mathrm{~mm}$ for socket welded joints.

\subsection{Strength tests}

The sleeve joints were tested for tensile strength on a Zwick/Roell Z150 testing machine. The tests were carried out in accordance with the valid: PN-EN ISO 9311-2:2011 standard [22]. The initial test force was $5 \mathrm{~N}$ and the crosshead speed $20 \mathrm{~mm} / \mathrm{min}$.

\section{Strength test results}

The results of strength tests are shown in Fig. 7.

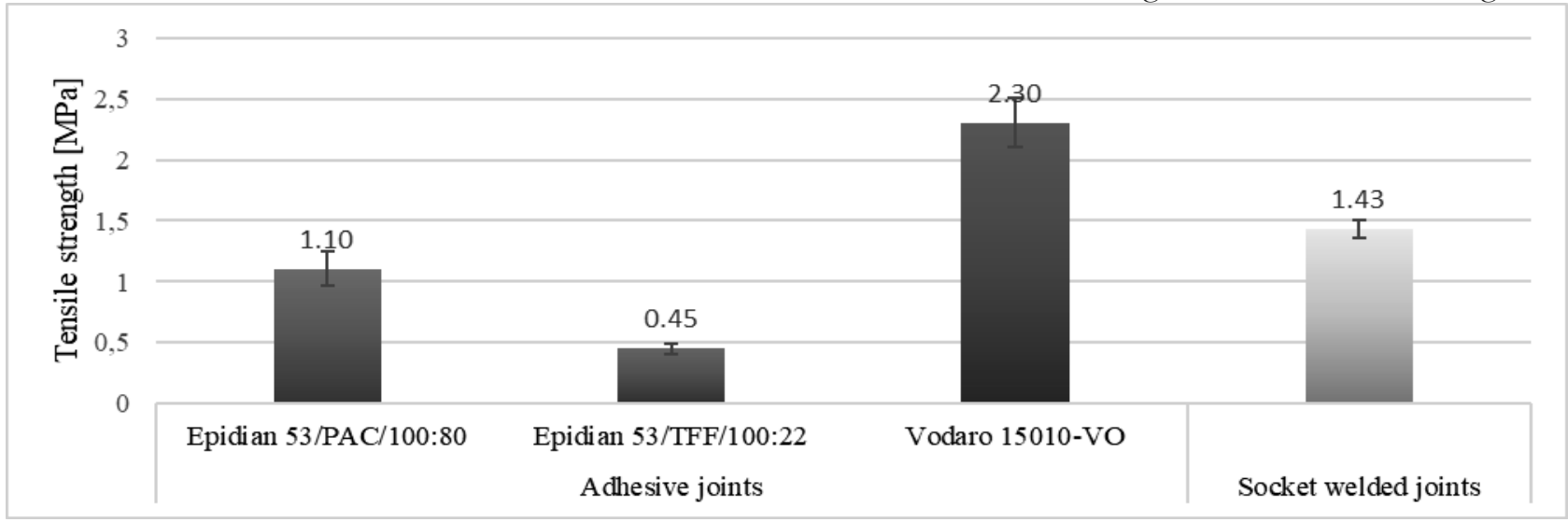

Fig. 7 Results of strength tests of sleeve joints

On the basis of the results presented in Fig. 7, it can be seen that the samples of adhesive joints of PVC-U pipes made with Vodaro 15010-VO adhesive showed the highest tensile strength - 2.30 MPa. The tensile strength obtained by the samples welded with PP-R was 62.18\% lower and was $1.43 \mathrm{MPa}$. The lowest value of strength among all the joints showed the adhesive joints made with Epidian 53/TFF/100:22 epoxy adhesive composition and was only $0.45 \mathrm{MPa}$, which constituted only $19.53 \%$ of the strength of Vodaro adhesive joints. It should be noted that as far as the repeatability of the results is concerned, it is stable in the case of all joints - the size of standard deviation was in the range of $5-13 \%$.

The reason for such results in the case of adhesive joints can be found in the properties of the adhesives used. Epoxy adhesives can be regarded as universal adhesives, as they are suitable for bonding metals, glass or ceramics. Vodaro is an adhesive dedicated to joining elements made of PVC and CPVC. In the case of PP-R material, welding is used, as this method of assembly is recommended for joining elements made of this material, as it has worse adhesion properties compared to elements made of PVC, which was observed during preliminary tests.

However, in order to be able to compare the results obtained, a statistical analysis of the results was carried out. In the first stage, using the Shapiro-Wilk S-W normality test, the adjustment of the obtained empirical results of the analysed variables to the normal distribution was checked, with the assumed level of confidence $\alpha=0.05$. The results of the normality test presented in Tab. 4 indicate that the distribution of the obtained results in not all cases is consistent with normal distribution.

On the basis of the results obtained, it can be seen that the condition of normal distribution in all groups was not met $(\mathrm{p}<0.05)$. Therefore, a non-parametric test was used in further analysis to compare multiple independent samples. The Kruskal-Wallis test was used. Assuming the significance level $\alpha=0.05$, it was checked if the mean values of shear strength of adhesive joints for particular compositions did not differ significantly. The results of these tests are presented in Tab. 5. 
Tab. 4 Normality test results

\begin{tabular}{|c|c|c|c|}
\hline \multicolumn{2}{|c|}{ Type of joint } & $\begin{array}{c}\text { Shapiro-Wilka statistics } \\
\text { W }\end{array}$ & $\begin{array}{c}\text { Probability level } \\
\mathrm{p}\end{array}$ \\
\hline \multirow{2}{*}{\begin{tabular}{c} 
T. \\
\cline { 2 - 4 }
\end{tabular}} & Epidian 53/PAC/100:80 epoxy adhesive composition & 0.869964 & 0.122844 \\
\cline { 2 - 4 } & Epidian 53/TFF/100:22 epoxy adhesive composition & 0.869457 & 0.121317 \\
\hline \multirow{2}{*}{$\begin{array}{c}\text { Vodaro 15010-VO } \\
\text { one-component adhesive }\end{array}$} & 0.846263 & 0.067771 \\
\hline \multirow{2}{*}{ Socket welded joints } & 0.802629 & 0.021882 \\
\hline
\end{tabular}

Tab. 5 Results of the non-parametric ANOV A Kruskala-W allisian ranks test

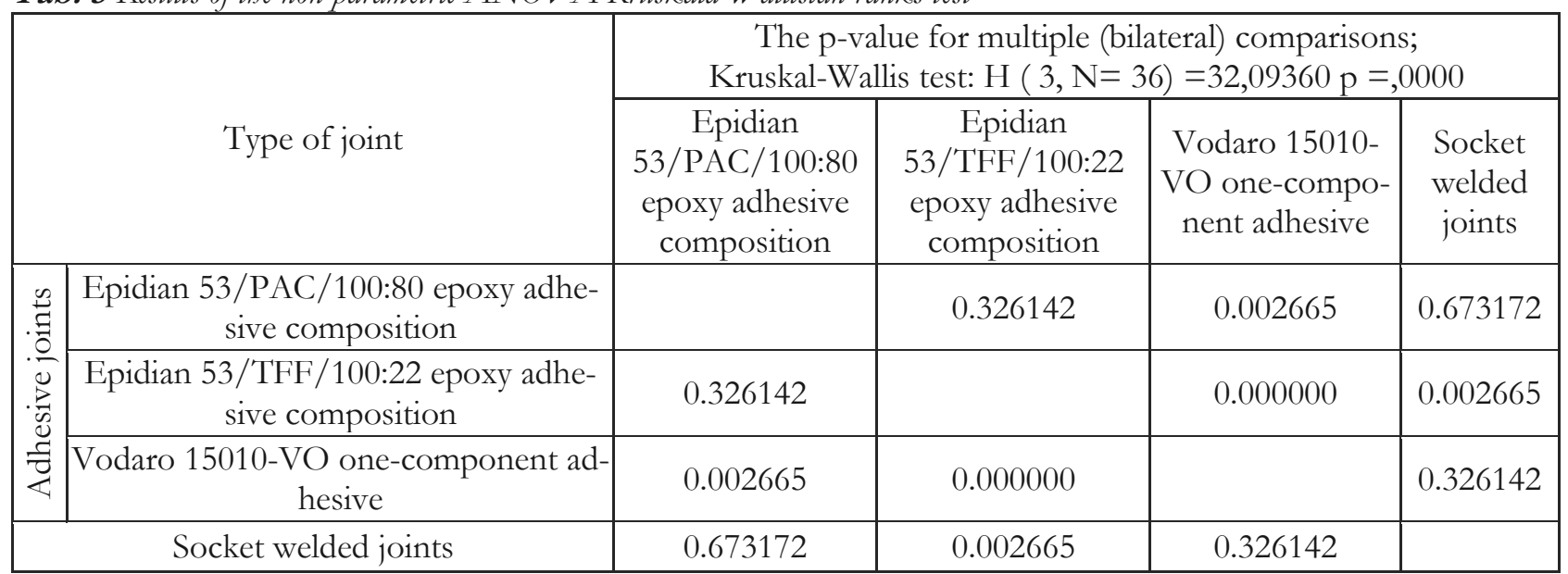

On the basis of the obtained results of statistical analyses it can be observed that significant differences at the assumed level of significance occur between adhesive joints made with epoxy adhesive compositions and those made with Vodaro one-component adhesive. Significant differences also occur between welded joints and joints made with Epidian 53/TFF/100:22 adhesive composition. At the assumed level of significance $\alpha=0.05$ no significant differences were observed in the case of joints made with single-component Vodaro adhesive and welded joints as well as in the case of welded joints and those made with Epidian 53/PAC/100:80 epoxy adhesive composition.

\section{Discussion of results}

Rudawska A., Abdel Wahab M. and Müller M. [21] presented the issues related to the impact of the adhesive sleeve joints ageing process (aged in the aqueous environment) on the selected mechanical properties of these joints. These joints were made using the different epoxy adhesives. Based on the obtained results, it was noticed that the longer the ageing time of the adhesive joint samples, the more negative effects on the adhesive joints (decreased strength regardless of the adhesive type or the material). In case of tubes made of both galvanised and carbon steel, such joints could work well in short-term exploitation as they would keep their strength for a certain period of time. The conducted research shows that technological factors (type of adhesive, type of adherends) as well as opera- ting factors $[21,23]$ are extremely important when designing adhesive joints, including sleeve joints.

The samples of the adhesive sleeve joints were examined with respect to failure patterns based on visual valuation and the standard PN-EN ISO 10365 [32]. Base on the failure patterns results it can be noticed that the most frequent failure pattern is a special cohesive failure (SCF) and cohesive failure (CF), for Epidian 53/TFF/100:22 epoxy adhesive composition, whereas the most frequent pattern of failure in the sleeve adhesive joints made of Vodaro 15010-VO adhesive is cohesive failure $(\mathrm{CF})$.

On the basis of the presented test results, it can be seen that the results of the strength of the adhesive joints show a strong correlation with the tensile strength of the adhesives themselves - the higher tensile strength of the adhesive, the higher strength of adhesive joints. Attention should also be paid to the accuracy of the joints. Greater dimensional repeatability was achieved in the case of adhesive joints than in socket welded joints. The highest dimensional repeatability was characteristic of joints made with Vodaro 15010-VO adhesive and also the highest tensile strength. This may be due to the properties of the adhesive itself. Among the adhesives used, Vo-daro is characterized by the lowest density and the lowest viscosity, thanks to which it was possible to make ac-curate adhesive joints. Epidian 53/TFF/100:22 adhesive composition is characterized by highest stiffness, in comparison with, among others, compositions cured with PAC curing agent [23], which could have caused the joints made with this adhesive composition to have 
the lowest strength.

\section{Conclusions}

The aim of the presented research was to compare the strength of sleeve joints made with different assembly methods. The choice of assembly method depended on the material used. The adhesive joints were made of polyvinyl chloride PVC-U pipes and welded joints of polypropylene PP-R pipes. The tests were carried out on butt joints with the following fittings.

After the experimental tests and analysis of the obtained research results, the following conclusions were formulated:

- PP-R adhesive joints made with Vodaro15010-VO single-component adhesive have the highest tensile strength, which means that in the case of any installation or construction where the method of assembling the structural elements is adhesive bonding, the best solution is to use dedicated adhesives.

- The lowest strength value was demonstrated by adhesive joints made of Epidian 53/TFF/100:22 epoxy adhesive composition. It may result from the fact that adhesive compositions made of resin and TFF curing agent are characterized by higher stiffness in comparison with, among others, compositions cured with PAC curing agent .

- The lowest strength value was demonstrated by adhesive joints made of the most stiffness epoxy adhesive composition.

- In the case of plastic installations, it is worth considering the assembly method because, as shown in the studies presented, an appropriate selection of adhesive technology can bring comparable or even more satisfactory results than the welding method. In addition, it should be noted that welding requires special equipment and equipment and that during the welding process itself, the person making the assembly joint is exposed to burns due to the welding of the fixture parts, among other things.

Summarizing the conducted experimental research on adhesive and welded assembly joints, it can be stated that technological factors, such as proper preparation of the assembled elements, selection of the appropriate adhesive, careful preparation and applica- tion of the adhesive, selection of the appropriate method and parameters of the welding process, as well as pressure reinforcing the weld, and above all the type of material used in specific structures, have a major impact on the strength of the joints made.

\section{References}

[1] ADAMS, R.D., COMYN, J., WAKE, W.C. (1997). Structural adhesive joints in engineering. Chapman \& Hall.

[2] AMANCIO-FILHO, S.T., DOS SANTOS, J.F. (2009). Joining of polymers and polymermetal hybrid structures: Recent developments and trends. Polymer Engineering \& Science. Vol. 49, No. 8, pp.1461-1476.

[3] ARNOT'T, D., RIDER, A., MAZZA, J. (2002). Surface Treatment and Repair Bonding. Advances in the Bonded Composite Repair of Metallic Aircraft Structure. Elsevier. pp. 41-86.

[4] BAZROV, B.M. (2010). Classification of joints. Russian Engineering Research. Vol. 30, No. 4, pp. 399-403.

[5] CHEN, W.-F., KISHI, N., KOMURO, M. (2011). Semi-rigid connections handbook. J. Ross Pub.

[6] DEBROY, T., DAVID, S.A. (1995). Physical processes in fusion welding. In: Reviews of Modern Physics. Vol. 67, No. 1, pp. 85-112.

[7] DOLEZ, P. AND LOVE, B. (2001). Adhesive bonding as an alternative for underwater structural repair. Eleventh International Offshore and Polar Engineering Conference. ISOPE, International Society of Offshore and Polar Engineers. pp. 17-22.

[8] GAUGEL, T., BENGEL, M., MALTHAN, D. (2004). Building a mini- assembly system from a technology construction kit. In: Assembly $A u$ tomation. Vol. 24, No. 1, pp. 43-48.

[9] GREWELL, D., BENATAR, A. (2007). Welding of Plastics: Fundamentals and New Developments. International Polymer Processing. Vol. 22, No. 1, pp. 43-60.

[10] JASIULEK, P. (2004). Butt welding of polyethylene pipes. In: Instal. No. 4, pp. 40-44.

[11] JEŻEWSKA, A. (2015). Tetrahydrofuran Determination in workplace air with gas chromatography. In: Podstawy i Metody Oceny Środowiska Pracy. Vol. 86, No. 4, pp. 191-202.

[12] KEIBAL, N.A., BONDARENKO, S.N., KABLOV, V.F. (2011). Modification of adhesive compositions based on polychloroprene 
with element-containing adhesion promoters. In: Polymer Science Series D. Vol. 4, No. 4, pp. 267-280.

[13] KOU, S. (2003). Welding metallurgy. In. MRS Bulletin. Vol. 28, No. 9, pp. 674-675.

[14] KRÓLIKOWSKI, W. (2017). Polimerowe komposyty konstrukcyjne. PWN.

[15] KURUSHINA, V., ZEMENKOV, Y. (2014). Innovative cyclical development of the Russian pipeline system, pp. 881-888. Ekateringburg, Russia.

[16] KUSMIERCZAK, S. (2015). Evaluation of Degradation of Heat Stressed Pipelines, Manufacturing Technology, Vol. 15, No. 6, pp. 10061010.

[17] MITURSKA, I., RUDAWSKA, A., MÜLLER, M., VALÁŠEK, P. (2020). The Influence of Modification with Natural Fillers on the Mechanical Properties of Epoxy Adhesive Compositions after Storage Time. Materials. Vol. 13, No. 2, pp. 291.

[18] MÜLLER, M. (2017). Effect of Surface Treatment of Adhesive Bonded Sheet of Aluminium Alloy EN AW 2024 T3 on Adhesive Bond Strength Created by Means of Structural Two-Component Adhesive. Manufacturing Technology. Vol. 17, No. 5, pp. 791-796.

[19] MÜLLER, M. (2017). Effects of Aluminium Microparticles and Surface Treatment of AlCu4Mg on Mechanical Properties of Adhesive Bond Strength. Manufacturing Technology. Vol. 17, No. 1, pp. 66-71.

[20] RUDAWSKA, A. (2019). Comparison of the adhesive joints' strength of the similar and dissimilar systems of metal alloy/polymer composite. Applied Adhesion Science. Vol. 7, No. 1, pp. 7.

[21] RUDAWSKA, A., ABDEL WAHAB, M., MÜLLER, M. (2020). Effect of ageing process on mechanical properties of adhesive tubular butt joints in aqueous environment. International Journal of Adhesion and Adhesives. Vol. 96, 102466.

[22] RUDAWSKA, A., KUCZMASZEWSKI, J. (2005). Klejenie blach ocynkowanych. Wydawnictwo Politechniki Lubelskiej.

[23] RUDAWSKA, A., MITURSKA, I. (2018). Wpływ warunków utwardzania i sezonowania na wytrzymałość połączeń klejowych doczołowych. Technologia $i$ Automatyzacja Monta:zu. Vol. 4, pp. 48-52.

[24] RUDAWSKA, A., MITURSKA, I., SZABELSKI, J., SKOCZYLAS, A., DROŹDZIEL, P., BOCIĄGA, E., MADLEŇÁK, R., KASPEREK, D. (2017). Experimental research and statistic analysis of polymer composite adhesive joints strength. In: Journal of Physics: Conference Series. Vol. 842, pp. 012074.

[25] RUDAWSKA, A., WIERZCHOWSKI, A., MÜLLER, M., PETRŮ, J., NÁPRSTKOVÁ, N. (2017). The Properties of Regenerative Polymer Mass. Advances in Science and Technology Research Journal. Vol. 11, No. 3, pp. 130-138.

[26] ŚCIESZKA, S.F., ŻOLNIERZ, M. (2012). Eksploatacja maşyn, część 1. Wydawnictwo Politechniki Śląskiej,.

[27] SIONKOWSKA, A. (2011). Current research on the blends of natural and synthetic polymers as new biomaterials: Review. In: Progress in Polymer Science. Vol. 36, No. 9, pp. 1254-1276.

[28] WŁOSIŃSKI, W. (2001). Methods of joining of special materials. In: Biuletyn Instytutu Spawalnictwa w Gliwicach. Vol. 45, No. 5, pp. 126-130.

[29] ZHANG, X., MAO, X., ABOURIZK, S.M. (2009). Developing a knowledge management system for improved value engineering practices in the construction industry. In: Automation in Construction. Vol. 18, No. 6, pp/ 777-789.

[30] ŻUCHOWSKA, D. (2000). Polimery konstrukcyjne: wprowadzenie do technologii $i$ stosowania. Wydawnictwa Naukowo-Techniczne.

[31] bttps://systemy-cisnieniowe.pl/poradniki/klejenierur-i-ksztaltek-z-tworayw-sztucznych/ [access date: 02.01.2020]

[32] ISO/DIS 10365: Adhesives — Designation of main failure patterns.

[33] PN-EN ISO 9311-2:2011 - Adhesives for thermoplastic piping systems -- Part 2: Determination of shear strength. 